Advances in Sustainable and Environmental Hydrology, Hydrogeology, Hydrochemistry and Water Resources pp 125-127| Cite as

\title{
Geochemical Classification of Groundwater System in a Rural Area of Nigeria
}

- Authors

- Authors and affiliations

- Theophilus A. Adagunodo

- Rachael O. Adejumo

- Anuoluwapo M. Olanrewaju

$\bullet$

○

Chapter

First Online: 15 March 2019

- 9Downloads

Part of the Advances in Science, Technology \& Innovation book series (ASTI)

\section{Abstract}

The characteristics of the groundwater system in Iresa-Apa, Oyo state, Nigeria, were studied using the Piper linear approach. Twenty-four water samples were randomly collected to cover the area of study. The analyzed cations from the samples are $\mathrm{Mg}^{2+}, \mathrm{Na}^{+}, \mathrm{K}^{+}$, and $\mathrm{Ca}^{2+}$, while the anions are $\mathrm{CO}_{3}^{2-}, \mathrm{HCO}_{3}^{-}, \mathrm{SO}_{4}^{2-}$, and $\mathrm{Cl}^{-}$. The three hydrochemical facies identified are $\mathrm{Ca}-\mathrm{Mg}-$ $\mathrm{Na}, \mathrm{Ca}-\mathrm{Mg}-\mathrm{Na}-\mathrm{SO}_{4}$, and $\mathrm{Na}-\mathrm{K}-\mathrm{Cl}-\mathrm{SO}_{4}$ types. The similarities in the observed water types suggest that almost the same geochemical processes are controlling the cation-anion reaction of the groundwater system in the study area.

\section{Keywords}

Geochemical Groundwater classification Hydrochemical facies IresaApa Cations and anions

https://link.springer.com/chapter/10.1007/978-3-030-01572-5 31 


\section{References}

1. 1.

Adagunodo, T.A.: Groundwater Pollution and Control: An Overview. Chapter 1 in Book: Groundwater Contamination: Performance, Limitations and Impacts, pp. 1-135. ISBN: 978-1-153611-017-3; 978-1-53611-003-6. Editor: Anna L. Powell (C) 2017 Nova Science Publishers, Inc. pp. 1-12 (2017a) Google Scholar

2. 2.

Adagunodo, T.A.: Groundwater Contamination: Performance, Effects, Limitations and Control. Chapter 3 in Book: Groundwater Contamination: Performance, Limitations and Impacts, pp. 1-135. ISBN: 978-1-153611-017-3; 978-1-53611-003-6. Editor: Anna L. Powell (C) 2017 Nova Science Publishers, Inc. pp. 33-64 (2017b) Google Scholar

3. 3.

Adagunodo, T.A., Akinloye, M.K., Sunmonu, L.A., Aizebeokhai, A.P., Oyeyemi, K.D., Abodunrin, F.O.: Groundwater exploration in Aaba residential area of Akure, Nigeria. Front. Earth Sci. 6, 66 (2018). https://doi.org/10.3389/feart.2018.00066

4. 4.

Adagunodo, T.A., Sunmonu, L.A., Ojoawo, A., Oladejo, O.P., Olafisoye, E.R.: The hydro geophysical investigation of Oyo State industrial estate Ogbomosho, Southwestern Nigeria using vertical electrical soundings. Res. J. Appl. Sci. Eng. Technol. 5(5), 18161829 (2013) CrossRefGoogle Scholar

5. 5.

Adejumo, R.O., Adagunodo, T.A., Bility, H., Lukman, A.F., Isibor, P.O.:

Physicochemical constituents of groundwater and its quality in crystalline bedrock, Nigeria. Int. J. Civ. Eng. Technol. 9(8), 887-903 (2018)Google Scholar

6. 6.

APHA: Standard Methods for the Examination of Water and Wastewater. American Public Health Association, Washington DC (1998) Google Scholar

7. 7.

Ganiyu, S.A., Badmus, B.S., Olurin, O.T., Ojekunle, Z.O.: Evaluation of seasonal variation of water quality using multivariate statistical analysis and irrigation parameter indices in Ajakanga area, Ibadan, Nigeria. Appl. Water Sci. 8, 35 (2018) CrossRefGoogle Scholar

8. 8.

Maxwell, O., Wagiran, H., Ibrahim, N., Lee, S.K., Soheil, S.: Comparison of ${ }_{238} U$, ${ }_{23} T h$, and ${ }_{40} \mathrm{~K}$ in different layers of subsurface structures in Dei-Dei and Kubwa, Abuja Northcentral Nigeria. Radia. Phys. Chem. 91, 70-80 (2013)rossRefGoogle Scholar

9. 9 . 
Narsimha, A., Venkatayogi, S., Geeta, S.: Hydrogeochemical data on groundwater quality with special emphasis on fluoride enrichment in Menneru River Basin (MRB), Telangana state, South India. Data Brief 17, 339-346 (2018)CrossRefGoogle Scholar

10.10.

Offodile, M.E.: The occurrence and exploitation of groundwater in Nigeria Basement rocks. Journal of Mining and Geology 2o, 131-146 (1983)Google Scholar

Selvakumar, S., Chandrasekar, N., Kumar, G.: Hydrogeochemical characteristics and groundwater contamination in the rapid urban development areas of Coimbatore, India. Water Resour. Ind. 17, 26-33 (2017)CrossRefGoogle Scholar

WHO: Guidelines for Drinking-Water Quality. First Addendum to 3rd edn.

Recommendations. World Health Organization, Geneva (2004) Google Scholar

\section{Copyright information}

(C) Springer Nature Switzerland AG 2019

\section{About this chapter \\ CrossMark}

\section{Cite this chapter as:}

Adagunodo T.A., Adejumo R.O., Olanrewaju A.M. (2019) Geochemical Classification of Groundwater System in a Rural Area of Nigeria. In: Chaminé H., Barbieri M., Kisi O., Chen M., Merkel B. (eds) Advances in Sustainable and Environmental Hydrology, Hydrogeology, Hydrochemistry and Water Resources. Advances in Science, Technology \& Innovation (IEREK Interdisciplinary Series for Sustainable Development). Springer, Cham

- First Online15 March 2019

- DOlhttps://doi.org/10.1007/978-3-030-01572-5_31

- Publisher NameSpringer, Cham

- Print ISBN978-3-030-01571-8

- Online ISBN978-3-030-01572-5

- eBook PackagesEarth and Environmental Science

- Buy this book on publisher's site

- Reprints and Permissions 